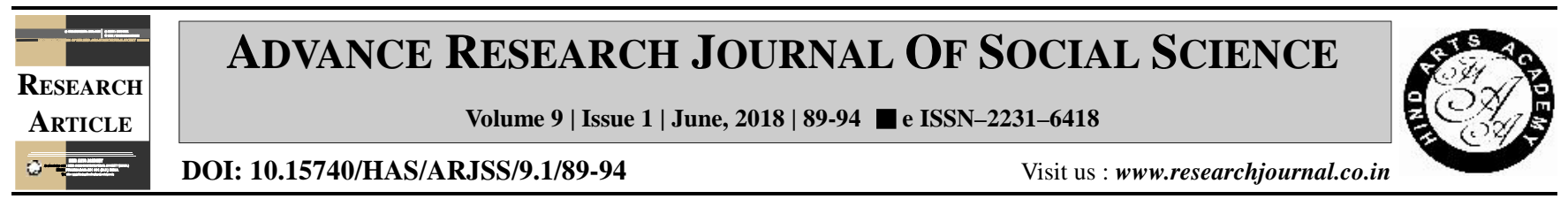

\title{
Knowledge on reproductive health care in Agrarian families
}

S. Amutha*, Veeran Arun Giridhari ${ }^{1}$ and C.P. Sanjana ${ }^{1}$

Community Science College and Research Institute, Madurai (T.N.) India

${ }^{1}$ AICRP on Home Science, Community Science College and Research Institute, Madurai (T.N.) India

\section{ARTICLE INFO :}

$\begin{array}{lll}\text { Received } & : & 04.04 .2018 \\ \text { Revised } & : & 08.05 .2018 \\ \text { Accepted } & : & 22.05 .2018\end{array}$

\section{KEY WORDS :}

Knowledge on reproductive health, Maternal health, Rural women, Agrarian families

\section{HOW TO CITE THIS ARTICLE :}

Amutha, S., Giridhari, Veeran Arun and Sanjana, C.P. (2018). Knowledge on reproductive health care in Agrarian families. Adv. Res. J. Soc. Sci., 9 (1) : 8994, DOI: 10.15740/HAS/ARJSS/9.1/89. 94.

Copyright@2018 : Hind Agri Horticultural Society

*Author for correspondence

\begin{abstract}
The study was aimed to perceive the knowledge on reproductive health of rural women by interviewing 300 women belonging to Agrarian families (age group of 20-45 years) who were randomly selected from five villages of Vadipatti taluk, Alanganallur block of Madurai district. The socio-economic status scale developed by Agarwal et al. (2005) was used to study the socio-economic status of rural farm women, Reproductive health knowledge checklist and Maternal and child health checklist prepared by PJTSAU AICRP-CD component was used to assess the knowledge regarding reproductive health. Wellbeing assessment tool developed by Mc Kinley Health Center at the University of Illionois was used to assess the well being of women. The results indicated that majority of the rural farm women had good knowledge and some of them had average knowledge on reproductive health. Even though the agrarian families were having good knowledge regarding reproductive health, there is a need to put efforts to improve the health and hygiene aspects such as hygienic napkin usage and disposal. Required resource material should be developed for empowering agrarian families quality life style regarding hygienic life through giving various interventions like napkin production which in turns helps for economic empowerment. Education and SES status predicts the knowledge regarding reproductive health. Hence, the farming community especially the rural women should be educated with creating awareness about the reproductive health and the availability of different services provided by the government so that they have the healthy reproductive life.
\end{abstract}

